\title{
Pengaruh Insentif dan Kepuasan Kerja Terhadap Kinerja Karyawan Pada Hotel Grand Zuri Duri
}

\author{
SUDARMIN MANIK $^{1}$, NOVA SYAFRINA ${ }^{2}$ \\ ${ }^{1,2}$ Sekolah Tinggi Ilmu Ekonomi Riau \\ Jln. HR. Subrantas No. 57 Panam Pekanbaru \\ E-mail : amin.manik@yahoo.com
}

\begin{abstract}
The purpose of this study is to determine the effect of incentives and job satisfaction on employee performance at Hotel Grand Zuri Duri. The population in this study were employees of Hotel Grand Zuri Duri which amounted to 104 people. And the sample numbered 51 people using slovin formula. Data analysis was performed using reliability test, normality, $\mathrm{F}$ test, multiple linear regression, $\mathrm{R} 2$ test and $\mathrm{t}$ test. The test is conducted in order to determine the effect of work discipline on employee performance at Hotel Grand Zuri Duri. Based on the result of research that service quality simultaneously incentive and job satisfaction with adjusted $\mathrm{R}$ square value can 0,960 , which means incentive and job satisfaction contributed $96,00 \%$ contribution to employee performance, and have positive and significant influence to employee performance with level of sig . 0,000. The conclusion from the research that hypothesis simultaneously incentives and job satisfaction can be accepted truth. While on the partial incentive test has no significant effect on employee performance and job satisfaction have a significant effect on employee performance.
\end{abstract}

Keywords: Incentives, Job Satisfaction, employee performance

Suatu perusahaan Sumber Daya Manusia merupakan sentral atau kekuatan yang dapat menggerakkan jalannya organisasi. Sumber Daya Manusia merupakan asset yang paling penting dalam sebuah organisasi. Sehingga dapat dikatakan tanpa adanya Sumber Daya Manusia perusahaan tidak akan berjalan sesuai yang diinginkan.

Suatu perusahaan yang dilengkapi dengan peralatan canggih tidak akan menjamin akan berjalan dengan lancar tanpa adanya karyawan. Keberhasilan suatu perusahaan dapat dilihat dari kinerja karyawan yang ada. Semakin baik kinerja karyawan, pasti akan meningkatkan income bagi perusahaan. Untuk mendapatkan hasil kerja yang maksimal, sumber daya manusia harus dikelola secara baik, sehingga dapat kegiatan operasional pada perusahaan akan lancar.

Setiap perusahaan profit pastinya akan meningkatkan pendapatan yang semaksimal mungkin. Sama dengan halnya Hotel Grand Zuri Duri yang bergerak dibidang jasa, pastinya harus memiliki karyawan yang berkopetensi dan memiliki kinerja yang baik. Berikut jumlah turnover karyawan Hotel Grand Zuri Duri dalam kurun waktu lima tahun terakhir.

Tingkat turnover karyawan pada Hotel Grand Zuri Duri mengalami fluktuatif. Dengan berfluktuatifnya tingkat turnover karyawan dapat dipastikan karyawan Hotel Grand Zuri kurang puas dalam bekerja. Jika karyawan kurang puas maka dapat menyebabkan kinerja yang kurang baik. Kurang puasnya karyawan dapat di sebabkan oleh beberapa faktor, salah satunya adalah insentif. Dengan adanya insentif yang sesuai maka akan meningkatkan kepuasan kerja karyawan. Berikut data pemberian insentif pada Hotel Grand Zuri Duri dalam kurun waktu lima tahun terakhir

Insentif yang diberikan perusahaan mengalami penurunan pada tahun terakhir. Hal ini dapat mengakibatkan semangat kerja karyawan menurun dan akan berdampak pada kinerja karyawan. Jika kinerja karyawan menurun, akan mengakibatkan turunnya income yang di dapat perusahaan. Hal ini dapat dilihat dari 
kamar yang terjual pada Hotel Grand Zuri Duri.

Penjualan kamar pada Hotel Grand Zuri selalu mengalami penurunan. Sehingga pendapatan yang diperoleh perusahaan menurun. Dengan menurunnya tingkat penjualan kamar dapat dipastikan kinerja karyawan juga menurun.

Dari latarbelakan masalah dan fenomena yang ada, maka penulis merumuskan masalah sebagai berikut: Ada pengaruh antara insentif dan kepuasan kerja terhadap kinerja karyawan pada Hotel Grand Zuri Duri.

Dessler dalam Sutrisno (2016) manajemen sumber daya manusia dapat didefinisikan suatu kebijakan dan praktik yang diperlukan seseorang yang menjalankan aspek orang atau sumber daya manusia dari posisi seseorang manajemen, mulai dari perekrutan sampai dengan penilaian

Manajemen Sumber Daya Manusia adalah ilmu dan seni mengatur hubungan dan peranan anggota organisasi agar efektif dan efisien agar terwujudnya tujuan perusahaan, karyawan, dan masyarakat (Melayu Hasibuan, 2016)

Sinambela (2016) Manajemen SDM dapat didefinisikan sebagai suatu pengelolaan dan pendayagunaan sumber daya yang ada pada individu. Sihotang dalam Sinambela (2016:8) MSDM adalah keseluruhan proses perencanaan, pengorganisasian, pengarahan dan pengawasan terhadap kegiatan pengadaan seleksi, pelatihan, penempatan, pemberian kompensasi, pengembangan, pengitegrasian, pemeliharaan, dan pelepasan SDM untuk tercapainya berbagai tujuan individu, masyarakat, pelanggan pemerintah dan organisasi yang bersangkutan.

Menurut Fahmi (2014) kinerja adalah hasil yang diperoleh oleh suatu anggota organisasi baik organisasi tersebut bersifat profit oriented dan non profit oriented yang dihasilkan selama kurun waktu tertentu.

Wibowo (2007) kinerja merupakan hasil kerja yang mempunyai hubungan kuat dengan tujuan organisasi, memberikan kontribusi pada ekonomi. Dengan demikian, kinerja adalah tentang bagaimana melakukan pekerjaan dan bagaimana cara mengerjakannya. Kinerja adalah hasil kerja yang telah dicapai pegawai dari tingkah laku kerjanya dalam melaksanakan kerja (Edy Sutrisno, 2015).

Simanjuntak dalam Rivai (2009:406) kinerja adalah tingkat pencapaian hasil atas pelasksanaan tugas tertentu. Bastian dalam Fahmi (2014:128) kinerja adalah gambaran mengenai tingkat pencapaian pelaksanaan suatu kegiatan/program/kebijaksanaan dalam mewujudkan sasaran tujuan, misi dan visi organisasi yang tertuang dalam perumusan skema strategik suatu organisasi.

Untuk memudahkan pengkajian kinerja pegawai, Iebih lanjut Rina Marsinta dalam buku Sedarmayanti (2009:51) mengemukakan indikator-indikator kinerja yaitu sebagai berikut: Kualitas Kerja. Adalah kualitas kerja yang diapai berdasarkan syarat-syarat kesesuain dan kesiapannya yang tinggi pada gilirannya akan melahirkan penghargaan dan kemajuan serta perkembangan organisasi melalui peningkatan pengetahuan keterampilan secara sistematis sesuai tuntutan ilmu pengetahuan dan teknologi yang semakin berkembang pesat. Ketetapan Waktu. Adalah berkaitan dengan sesuai atau tidaknya waktu penyelesaian pekerjaan dengan target waktu yang direncanakan. Setiap pekerjaan diusahakan untuk selesai sesuai dengan rencana agar tidak mengganggu pekerjaan yang lainnya. Inisiatif. Adalah mempunyai kesadaran diri untuk melakukan sesuatu dalam melaksanakan tugas-tugas dan tanggung jawab. Bawahan atau pegawai dapat melaksanakan tugas tanpa harus bergantung terus menerus kepada atasan. Kemampuan. Adalah diantara beberapa faktor yang mempengaruhi kinerja seseorang yang ternyata dapat diintervensi atau diterapi melalui pendidikan dan latihan.

p.ISSN: $2407-800 \mathrm{X} \quad$ e.ISSN: 2541-4356 
Komunikasi. Merupakan interaksi yang dilakukan oleh atasan kepada bawahan untuk mengemukakan saran dan pendapatnya dalam memecahkan masalah yang dihadapi. Komunikasi akan menimbulkan kerjasama yang lebih baik dan akan terjadi hubungan yang semakin harmonis diantara pegawai dan atasan yang juga dapat menimbulkan perasaan senasib dan sepenanggungan.

Menurut Handoko dalam Mangkunegara (2011:89) insentif adalah untuk meningkatkan motivasi karyawan dalam mencapai tujuan organisasi. Insentif adalah suatu penghargaan dalam bentuk uang yang diberikan oleh pihak pemimpin organisasi kepada karyawan agar mereka bekerja dengan motivasi yang tinggi dan berprestasi dalam mencapa tujuan-tujuan organisasi. (Mangkunegara, 2011:89)

Menurut Simamora dalam

Kadarisman (2014:182) kompensasi insentif merupakan program-program kompensasi yang mengaitkan bayaran (pay) dengan produktivitas. Tujuan mendasar dari insentif yaitu meningkatkan produktivitas para karyawan guna mencapai suatu keunggulan kompetitif. Program-program insentif membayar seorang individu atau kelompok untuk apa yang secara persis dihasilkannya. (Kadarisman, 2014:201)

Menurut Melayu S.P Hasibuan (2012:118) mengemukakan bahwa insentif adalah tambahan balas jasa yang diberikan kepada karyawan tertentu yang prestasinya di atas prestasi standar. Insentif ini merupakan alat yang di pergunakan pendukung prinsip adil dalam pemberian kompensasi. Sedangkan menurut Rivai (2008:362) insentif merupakan imbalan langsung yang dibayarakan kepada karyawan karena kinernya melebihi standar yang dibutuhkan atau ditentukan.

Menurut Hasibuan (2009:94), indikator pemberian insentif bagi karyawan antara lain sebagai berikut: Fasilitas. Fasilitas adalah kenikmatan atau fasilitas seperti mobil perusahaan, keanggotaan klub, tempat parker khusus atau akses kepesawatan perusahaan Jurnal Daya Saing (Vol. 4, No. 1 Feb 2018) yang didapat karyawan. Fasilitas dapat mewakili jumlah substansi dari insentif terutama eksekutif yang dibayar mahal. Lama karyawan bekerja. Besarnya insentif ditentukan atas dasar lamanya karyawan melaksanakan atau menyelesaikan suatu pekerjaan. Cara perhitungannya dapat menggunakan per jam, per hari, per minggu ataupun per bulan. Kebutuhan. Cara ini menunjukkan bahwa insentif pada karyawan didasarkan pada tingkat urgensi kebutuhan hidup yang layak dari karyawan. Ini berarti insentif yang diberikan wajar apabila dapat dipergunakan untuk memunuhi sebagian kebutuhan pokok, tidak berlebihan namum tidak berkekurangan. Hal seperti ini memungkinkan karyawan untuk dapat bertahan dalam perusahaan. Keadilan dan Kelayakan. Dalam sistem insntif bukanlah harus sama rata tanpa pandang bulu tetapi harus terkait pada adanya hubungan antara pengorbanan (input) dengan (output), makin tinggi pengorbanan semakin tinggi insentif yang diharapkan sehingga oleh karyawan yang harus dinilai adalah pengorbanannya yang diperlukan oleh suatu jabatan. Layak pengertiannya membandingkan besarnya insentif dengan perusahaan lain yang bergerak dalam bidang uasaha sejenis. Apabila insentif di dalam perusahaan yang bersangkutan lebih rendah dibandingkan dengan perusahaan lain maka perusahaan akan mendapat kendala yakni berupa menurunnya kinerja karyawan yang dapat diketahui dari berbagai bentuk akibat ketidakpuasan karyawan mengenai insentif tersebut. Evaluasi Jabatan. Evaluasi jabatan adalah suatu usaha untuk menentukan dan membandingkan nilai suatu jabatan tertentu dengan nilai jabatan-jabatan lain suatu organisasi. Ini berarti pula penentuan nilai relative atau harga dari suatu jabatan guna menyusun rangking dalam penentuan insentif.

Menurut Sutrisno kepuasan kerja adalah suatu sikap karyawan terhadap pekerjaan yang berhubungan

p.ISSN: $2407-800 X \quad$ e.ISSN: 2541-4356 
dengan situasi kerja, kerja sama antar karyawan, imbalan yang diterima dalam kerja dan hal-hal yang menyangkut faktor fisik dan psikologi.

Kepuasan kerja adalah perasaan menyokong atau tidak menyokong yang dialami karyawan (pegawai) dalam bekerja. (Keith Davis dalam Mangkunegara, 2011:117)

Kepuasan kerja mencerminkan perasaan seseorang terhadap pekerjaannya. Kepuasan kerja adalah keadaan emosional yang menyenangkan atau tidak menyenangkan di mana para karyawan memandang pekerjaannya. (Moh. As'ad dalam Sunyoto, 2012:26)

Dari beberapa defenisi diatas dapat disimpulkan bahwa kepuasan kerja adalah suatu sikap yang dirasakan oleh karyawan dalam melakukan tugas dan keawajiban yang diberikan oleh perusahaan.

Menurut Hasibuan (2008:202) indikator kepuasan kerja adalah sebagai berikut : Menyenangi pekerjaannya. Orang yang menyadari betul arah kemana ia menjurus, mengapa ia menempuh jalan itu dan bagaimana caranya ia harus menuju sasarannya. Ia menyenangi pekerjaannya karena ia bisa mengerjakannya dengan baik. Mencintai pekerjaannya. Memberikan sesuatu yang terbaik, mencurahkan segala bentuk perhatian dengan segenap hati yang dimiliki dengan segala daya upaya untuk satu tujuan hasil yang terbaik bagi pekerjaannya. Moral Kerja. Kesepakatan batiniah yang muncul dari dalam diri seseorang atau sekelompok orang untuk mencapai tujuan tertentu sesuai dengan baku mutu yang ditetapkan. Kedisiplinan. Kondisi yang tercipta dan terbentuk melalui proses dari serangkaian prilaku yang menunjukkan nilainilai ketaatan, kepatuhan, kesetiaan, keteraturan atau ketertiban. Prestasi kerja. Hasil kerja yang dicapai dalam melaksanakan tugas-tugas yang dibebankan kepadanya yang didasarkan atas kecakapan dan kesungguhan serta waktu.

\section{METODE}

Penelitian ini dilakukan di Hotel Grand Zuri Duri terletak di JL. Hangtuah No. 26 Duri Kecamatan Mandau Kabupaten Bengkalis.

\section{Jenis dan Sumber Data}

Adapun jenis data yang dapat penulis kumpulkan dalam penulisan skripsi ini adalah :

\section{Data Primer}

Data Primer yaitu data yang langsung diperoleh dan objek penelitian. (Sugiyono, 2010:14) Melalui wawancara dan kuisioner dengan pihak pimpinan dan karyawan pada Hotel Grand Zuri Duri.

\section{Data Skunder}

Data skunder yaitu data yang diperoleh dari sumber data yang ada kaitannya dengan penelitian. (Sugiyono, 2010:14) Berupa data yang sudah tersedia seperti data jumlah karyawan, struktur organisasi dan data lainnya yang mendukung analisa dalam penelitian ini.

\section{Teknik Pengumpulan Data}

Dalam penulisan skripsi ini, penulis menggunakan cara pengumpulan data sebagai berikut : Kuisioner adalah daftar pertanyaan yang disebarkan. (Sugiyono, 2010:106) Diberikan kepada seluruh karyawan pada Hotel Grand Zuri Duri. Untuk mengetahui pengaruh insentif terhadap kinerja karyawan, digunakan skala likert. Skala likert digunakan untuk mengukur sikap, pendapat dan presepsi seseorang atau kelompok orang tentang fenomenal sosial. Dengan skala likert, maka variabel yang diukur dan dijabarkan menjadi indikator variabel. Wawancara adalah mengadakan wawancara langsung ditempat objek penelitian. (Sugiyono, 2010:156) Dilakukan kepada pimpinan dan karyawan Hotel Grand Zuri Duri tentang berbagai informasi/data, untuk bahan

p.ISSN: $2407-800 X \quad$ e.ISSN: 2541-4356 
analisa yang diperlukan dalam penulisan skripsi ini.

Populasi. Populasi adalah keseluruhan subjek penelitian. Apabila seseorang ingin meneliti semua elemen yang ada dalam wilayah penelitian, maka penelitiannya merupakan penelitian populasi. (Suharsimi Arikunto, 2010:173) Populasi dalam penelitian ini dilakukan kepada seluruh karyawan pada Hotel Grand Zuri Duri yang berjumlah 104 orang.

Sampel. Sampel merupakan bagian dari jumlah dan karakteristik yang dimiliki oleh suatu populasi yang akan diteliti. Dalam penelitian ini penulis menggunakan teknik Simple Random Sampling. Menurut Sugiyono (2010:93) simple random sampling adalah teknik penggambilan anggota sampel yang dilakukan secara acak tanpa memperhatikan strata yang ada dalam populasi.

Berdasarkan populasi data diatas, menurut Umar (2005:78) untuk menentukan sampel digunakan pendapat slovin yaitu :

Keterangan :

$$
\mathrm{n}=\frac{\mathrm{N}}{1+\mathrm{Ne} 2}
$$

$\mathrm{n} \quad=$ Sampel

$\mathrm{N}=$ Populasi

$\mathrm{e}=$ Tingkat kesalahan penerikan sampel $10 \%$

Selanjutnya dengan mendistribusikan jumlah populasi kedalam rumus di atas maka diperoleh hasil sebagai berikut :

$\mathrm{n}=\frac{\mathrm{N}}{1+\mathrm{Ne} 2}$
$\mathrm{n}=\frac{104}{1+104(0,1) 2}$
$\mathrm{n}=\frac{104}{1+1,04}$

$\mathrm{n}=50,98$ (dibulatkan menjadi 51)

Uji reliabilitas berguna untuk menetapkan apakah instrumen yang dalam hal ini kuesioner dapat digunakan lebih dan satu kali, paling tidak oleh responden yang sama akan menghasilkan data yang konsisten. Dengan kata lain, reliabilitas instrumen mencirikan tingkat konsistensi. Nilai koefisien reliabilitas yang baik adalah diatas 0,6 (kuat), di atas 0,8 (sangat kuat). (Sugiyono, 2010:214)

Rumus Regresi Linier Berganda menurut Sugiyono (2012:261).

$\mathrm{Y}=\alpha+\beta 1 \mathrm{X} 1+\beta 2 \mathrm{X} 2+\varepsilon$

Dimana :

$\mathrm{Y} \quad=$ Kinerja Karyawan

$\alpha \quad=$ Konstanta

$\beta=$ Koefisien regresi

$\mathrm{X} 1=$ Insentif

$\mathrm{X} 2=$ Kepuasan Kerja

$\varepsilon=$ Standar Error

Uji $\mathrm{F}$ digunakan untuk mengetahui apakah variabel dependen (X1,dan X2) secara bersama-sama berpengaruh secara signifikan terhadap variabel dependen. Menurut Dwi Priyatno (2008:81) untuk mencari $\mathrm{F}$ hitung dengan rumus sebagai berikut:

$$
F \text { hitung }=\frac{R^{2} / k}{\left(1-R^{2}\right) /(n-k-1)}
$$

Keterangan:

$\mathrm{R}^{2} \quad=$ Koefisien determinasi

$\mathrm{n} \quad=$ Jumlah data

$\mathrm{k}=$ Jumlah variabel independen

Analisis determinasi dalam regresi linear sederhana yang digunakan untuk mengetahui persentase sumbangan pengaruh variabel independen terhadap variabel dependen $(\mathrm{Y})$.

Koefisien ini menunjukkan seberapa besar persentase variasi variabel independen yang digunakan dalam model dan mampu menjelaskan variasi variabel dependen. $\mathrm{R}^{2}$ sama dengan 0 , maka tidak ada sedikitpun persentase sumbangan pengaruh yang diberikan variabel independen terhadap variabel dependen atau variasi variabel independen yang digunakan dalam model tidak menjelaskan sedikitpun variasi variabel dependen.

Sebaliknya $\mathrm{R}^{2}$ sama dengan 1 , maka persentase sumbangan pengaruh yang 
diberikan variabel independen terhadap variabel dependen adalah sempurna, atau variasi variabel independen yang digunakan dalam model menjelaskan $100 \%$ variasi variabel dependen dan masing-masing variabel, baik variabel bebas terhadap variabel terikat yang signifikan secara statistik.

\section{HASIL}

Setelah data kuesioner terkumpul, maka dilakukan pengolahan data dengan bantuan komputer. Dan didapat outputnya sebagai berikut: Nilai Cronbach's alpha standardized lebih besar dari 0,70. Dimana kuesioner dikatakan reliabel jika nilai Cronbach's Alpha lebih besar dari 0,70. Setelah dilakukan uji reliabilitas diketahui nilai Cronbach's Alpha yang telah di standardized lebih besar dari 0,70 sehingga item pertanyaan variable-variabel pada tabel 4 dikatakan reliable dengan kesimpulan itemitem pertanyaan tersebut dapat diterima.

Hubungan Insentif, Kepuasan Kerja Tterhadap Kinrja Karyawan. Data ordinal yang telah diubah menjadi data interval kemudian dijumlahkan untuk tiap-tiap responden pada varaibel-variabel penelitian, dalam perhitungannya digunakan bantuan aplikasi IBM SPSS 19.

Dari hasil output SPSS diatas didapat persamaan regresi sebagai berikut:

$\mathrm{Y}=7,419+0,022 \mathrm{X} 1+1,081 \mathrm{X} 2$

Dari hasil tersebut dapat disimpulkan bahwa

a. Konstanta sebesar 7,419. Hal ini berarti jika insentif dan kepuasan kerja bernilai nol, maka kinerja karyawan masih bernilai 7,419 satuan.

b. Koefesien regresi insentif 0,022 . Hal ini berarti, jika variabel insentif dinaikkan 1 satuan dan variabel kepuasan kerja bernilai nol. Maka kinerja akan mengalami kenaikan sebesar 0,022 satuan

c. Koefisien regresi kepuasan kerja 1,081. Hal ini berarti, jika variabel kepuasan kerja dinaikkan 1 satuan dan variabel insentif bernilai nol. Maka kinerja karyawan akan mengalami kenaikan sebesar 1,081 satuan. Koefisien bernilai positif, jadi semakin besar insentif dan kepuasan kerja akan menaikkan kinerja karyawan.

Dari hasil regresi diatas dapat disimpulkan sebagai berikut

a. T hitung variabel insentif lebih kecil dari t tabel, dan tingkat signifikasi 0,659 lebih besar dari 0,05 . Hal ini berarti variabel insentif tidak signifikan terhadap kinerja karyawan.

b. T hitung variabel kepuasan kerja lebih besar dari t tabel, dan tingkat signifikasi 0,000 lebih kecil dari 0,05 . Hal ini berarti kepuasan kerja berpengaruh signifikan terhadap kinerja karyawan.

Dari hasil tersebut, bahwa hasil penelitian tersebut secara parsial variabel insentif dan kepuasan berpengaruh signifikan terhadap kinerja karyawan.

\section{PEMBAHASAN}

Dari hasil penelitian tersebut, maka pembahasan dalam penelitian ini adalah sebagai berikut: Bahwa secara simultan variabel insentif (X1) dan variabel kepuasan kerja (X2) berpengaruh signifikan terhadap kinerja karyawan. Hal ini karena tingkat signifikasi variabel insentif dan kepuasan kerja 0,000 lebih kecil dari $\alpha 5 \%$.

Sedangkan secara parsial variabel kepuasan berpengaruh signifikan terhadap kinerja karyawan, berarti Ha diterima dan Ho dan variabel insentif tidak signifikan terhadap kinerja karyawan. Koefisien regresi variabel insentif dan kepuasan bernilai positif, hal ini berarti semakin besar insentif dan kepuasan kerja, maka akan meningkatkan kinerja karyawan.Jadi untuk meningkatkan kinerja karyawan dapat dilakukan dengan cara meniingkatkan insentif dan memberikan kepuasan kerja terhadap karyawan. 


\section{SIMPULAN}

Dari hasil penelitian ini dapat disimpulkan beberapa hal sebagai berikut: Dari hasil output SPSS diatas nilai $\mathrm{R}=0,980$, hal ini berarti secara simultan insentif dan kepuasan kerja memiliki hubungan yang sangat erat terhadap kinerja karyawan. Sedangkan nilai Adjusted R square 0,960, hal ini berarti secara simultan insentif dan kepuasan kerja memberikan sumbangan pengaruh terhadap kinerja sebesar 96\%.Sedangkan dari hasil Uji t atau uji hipotesis bahwa secara parsial variabel insentif dan kepuasan berpengaruh signifikan terhadap kinerja karyawan

\section{DAFTAR RUJUKAN}

Arikunto, Suharsimi, 2010. Prosedur Penelitian, Edisi Revisi, Rineka Cipta, Jakarta.

Fahmi, Irham. 2014. Perilaku Organisasi. Alfabeta. Bandung

Hasibuan, Melayu, 2012. Manajemen Sumber Daya Manusia, Edisi Revisi, Cetakan XVI, PT. Bumi Aksara, Jakarta.

2008. Organisasi dan Motivasi, PT. Bumi Aksara, Jakarta.

Kadarisman, M, 2014. Manajemen Kompensasi, Cetakan ke II, Rajawali Pers, Jakarta.

Mangkunegara, A.A. Anwar Prabu, 2011. Manajemen Sumber Daya Manusia Perusahaan, PT. Remaja Rosdakarya, Bandung.

Priyatno, Duwi, 2008. Mandiri Belajar SPSS (Statistical Product and Service Solution), MediaKom, Yogyakarta.
Rivai, Veithzal. 2009. Manajemen Sumber Daya Manusia untuk Perusahan. PT. RajaGrafindo Persada. Jakarta

Sedarmayanti, 2009. Sumber Daya Manusia dan Produktifitas Kerja, $\mathrm{CV}$. Mandar Maju, Bandung.

Sinambela, Lijan Poltak. 2016. Manajemen Sumber Daya Manusia.Bumi Aksara. Jakarta

Sugiyono, 2010. Metode Penelitian Administrasi, Cetakan XVIII, Alfabeta, Bandung.

Sunyoto, Danang, 2012. Teori Kuesioner Dan Analisa Data Sumber Daya Manusia, Cetakan I, CAPS, Yogyakarta.

Sutrisno, Edy. 2016. Manajemen Sumber Daya Manusia. Prenadamedia Group. Jakarta 2015. Manajemen Sumber Daya Manusia,Kencana Prenada Media Group, Jakarta.

Umar Husein, 2005. Riset Pemasaran Dan Prilaku Konsumen, PT. Gramedia Pustaka Utama, Jakarta

Wibowo, 2007. Sistem Mananjemen Kinerja, PT. Raja Grafindo Persada, Jakarta 